\title{
MATHEMATICAL MODELLING OF QUALITY EDUCATION MONITORING
}

\section{МАТЕМАТИЧНЕ МОДЕЛЮВАННЯ МОНІТОРИНГУ ЯКОСТІ ОСВІТИ}

\section{Seleznova Nadiia ${ }^{1}$ \\ Rudyk Tetyana ${ }^{2}$}

DOI: http://dx.doi.org/10.30525/978-9934-571-27-5_46

\begin{abstract}
For Ukraine the availability of reliable, objective information on the state of the educational system is of particular importance in the modern period of reforming the education system. The quality of education, as the main measurement object in the course of monitoring researches, has a complex structure and needs comprehensive study. We propose a structural model for measuring the quality of education, built on mathematical models based on mathematical statistics. Most of the known methods of monitoring the quality of education are based on verbal methods, testing students, studying information, scientific and technical educational base. An approach to analyzing the quality of education through student rating marks is new and little studied. Therefore, in this paper a selection of materials published by the authors in recent years is presented and summarized, devoted to the correlation and statistical analysis of the coherence of educational marks. Using the Spirman correlation coefficients, a correlation matrix was constructed between different educational subjects based on student marks. The surprise was the presence of a negative coefficient of correlation between the two subjects, indicating the incoherence of the requirements of teachers to students from these subjects. When separating a certain group of subjects, for example natural sciences, it became clear that the correlation between these objects is rather small. This also indicates the inadequate teaching quality of these disciplines or poor pro-
\end{abstract}

\footnotetext{
${ }^{1}$ Candidate of Physical and Mathematical Sciences, Associate Professor, Associate Professor at the Department of Mathematical Physics,

National Technical University of Ukraine "Igor Sikorsky Kyiv Polytechnic Institute", Ukraine

${ }^{2}$ Candidate of Physical and Mathematical Sciences, Associate Professor,

Associate Professor at the Department of Mathematical Physics,

National Technical University of Ukraine "Igor Sikorsky Kyiv Polytechnic Institute", Ukraine
} 
vision of technical means. As it turned out in actual fact, the students were not provided with a sufficient amount textbooks. It was conducted with the help of correlation analysis and statistical point estimates the comparison of the results of success from mathematics of the first year study students of the two faculties of the "Igor Sikorsky Kyiv Polytechnic institute" with the results of external independent evaluation and entrance control on the preservation of knowledge in mathematics. The results showed that school marks of students of the first faculty were significantly higher than marks of students of the second and at the same time, the marks of entrance control showed significantly better results in mathematics from students of the second faculty. All this testifies to certain inadequacy in the evaluation of students ' knowledge of mathematics at school. The measure of stability of educational marks is considered as the ratio of standard deviation of row of the data measured in a certain scale, to half the scale base. Having assessed the achievements of students at the session on four subjects, stability indicators were calculated, which showed significant instability of the success of this group. This can be understood as a rather significant difference in the learning of educational material from various subjects. The content analysis of test tasks in mathematics and external independent evaluation was condacted in three different years, which showed structural deficiencies in the compilation of test tasks. Thus, the use of mathematical models for monitoring the quality of education can help in making managerial decisions and analyzing reforms in this area.

\section{1. Ветуп}

В даний час все частіше постає питання, що є якісною сучасною освітою, як виміряти іiі якість. Дати відповідь намагаються провідні вчені, відомі політики багатьох країн світу. ХХ ст. ознаменувалося тим, що розгорнулася так звана квалітативна революція, тобто революція якості, яка охопила всі сфери життя та діяльності людини. Якісний рівень освіти забезпечується за допомогою відповідних механізмів, що отримали назву моніторингу, під яким розуміють як систему збирання, опрацювання та розповсюдження інформації про діяльність освітньої системи, що забезпечує безперервне відстеження іiі стану, так і прогноз розвитку.

Педагогічний моніторинг - система відбору, обробки, аналізу, зберігання інформації про діяльність педагогічної системи в конкретному 
напрямку, що забезпечує безперервне тривале відстеження ii стану, корегування навчально-виховного процесу та прогнозування розвитку освітньої системи. В умовах оновлення освіти актуальними стають проблеми педагогічної діагностики. Неможливо досягти високого рівня навчальних досягнень учнів без відповідного контролю за ходом навчального процесу. Проблеми оцінювання навчальних досягнень учнів та оцінювання ефективності навчання пов'язані між собою.

Об'єктом дослідження в роботі є експертні оцінки, тобто навчальні оцінки успішності студентів.

Предметом дослідження є кореляційні та регресійні зв'язки між експертними оцінками.

Метою роботи є дослідження та побудова математичних моделей методами статистики та за допомогою статистичних показників на прикладі результатів успішності студентів. Дана мета реалізується шляхом виконання таких науково-дослідних завдань:

- методом кореляційного аналізу дослідити навчальні оцінки учнів з різних предметів;

- побудова багатофакторної кореляційної моделі;

- обчислення показників ентропії та узгодженості навчальних оцінок;

- провести контент аналіз завдань ЗНО.

Математичний апарат та технічні засоби, застосовані у роботі.

Математичним апаратом у запропонованій роботі є апарат математичної статистики, застосований до багатовимірних випадкових величин, а саме: визначення залежності між випадковими величинами успішністю студентів з різних предметів та зовнішнього незалежного оцінювання - 3 метою проведення аналізу ступеня впливу однієї випадкової величини на іншу та інформативності одних величин відносно інших, тобто визначення ступеня взаємообумовленості певних випадкових величин. Детальніше - кореляційний аналіз (обчислення кореляційних моментів або коефіцієнтів кореляції) [1, с. 492].

Обчислення були проведені в середовищі MS Excel, за допомогою прикладних пакетів програм з обробки та статистичного аналізу соціологічних даних.

Практична цінність дослідження грунтується на новизні та прикладному спрямуванні дослідження. Розроблена модель може застосовуватися на практиці при дослідженні взаємозв'язків між різними предметами. 


\section{Mathematical modelling of quality education monitoring}

Отримані у результаті дослідження дані можуть використовуватися для виявлення «слабких та сильних сторін» в процесі підготовки начального матеріалу, оптимізації та його поліпшення, аналізуючи кореляційні матриці успішності учнів, можна корегувати роботу викладачів.

За останні десятиріччя виділилась окрема галузь математики - «експертні оцінки», яка вважається самостійною математичною дисципліною і широко застосовується в прикладній соціології, економіці, педагогіці, моніторингу якості освіти [2, с. 159]. До неї входять, наприклад, такі розділи, як процедури побудови матриць парних порівнянь, методи i алгоритми суворого та несуворого ранжування об'єктів, моделі і методи прийняття рішень в умовах невизначеності, задачі і методи визначення компетентності експертів, кореляційно-регресійний аналіз, тощо.

Моніторинг педагогічного процесу та якості надання освіти може бути побудований на вербальних характеристиках, які зрештою дають досить суб'єктивні оцінки. Адже, опитуючи учнів та їх батьків про рівень викладання в навчальному закладі, отримують в цілому досить суб'єктивні оцінки.

Про якість освіти також можна судити за результатами тестування та професійної діяльності випускників навчального закладу та їх конкурентоздатності на ринку праці. У сучасній педагогічній науці недостатньо висвітлені підходи до виявлення критеріїв якості шкільної освіти, механізмів моніторингу та процесів його використання. В цілому моніторинг виконує роль процесу діагностування.

Внесення математичних методів у дослідження якості освітнього процесу навчального закладу надає досить високий рівень об'єктивності оцінки такого дослідження. Одним із методів моніторингу якості освіти є створення певної математичної моделі, яка адекватно буде описувати стан та рівень освіти у певному навчальному закладі.

Окремо виділяються в педагогічних дослідженнях формальні математичні моделі, що дозволяють надати цьому виду гуманітарних досліджень суто наукову форму, що характерна для досліджень в галузі точних наук.

Інколи математичні моделі поділяють на три взаємопов'язані групи:

1) детерміновані моделі, представлені у формі рівнянь та нерівностей, що описують певну систему; 2) моделі оптимізації, що дозволяють дослідити на екстремум цільову функцію при певних обмеженнях; 
3) ймовірнісні моделі, які включають в себе як кореляційно-регресійний аналіз, так і факторний аналіз, аналіз основних точкових статистичних показників, динамічні ряди.

\section{2. Постановка задачі}

Побудуємо математичну модель на основі статистичних методів дослідження узгодженості рейтингових оцінок учнів. Адже при традиційному нормативному оцінюванні - рейтингуванні оцінка для студента $є$ досить вагомою мотивацією навчання. Але при цьому може затінятися змістовний результат навчання. Отже, оцінка може стати засобом управління студентами, заохоченням або покаранням. Звідси випливає, що якість оцінювання результатів навчання учнів $є$ одним із чільних факторів учбового процесу.

При традиційному оцінюванні викладачі передусім оцінюють знання учнів, крім того на оцінку впливають також і суб'єктивні чинники, які при статистичному дослідженні великої сукупності нівелюються при достатній об'єктивності викладачів (в даному випадку вони виступають експертами), або навпаки, якісь суб'єктивні судження викладачів дають у статистичному дослідженні певні неточності. Саме це і дозволяє відслідковувати певні проблеми у навчальному процесі.

В більшості публікацій з моніторингу якості освіти присутні вербальні методи дослідження [3, с. 41,4 , с. $48 ; 5$, с. 7 ; 6, с. 18; 7, с. 10]. Методом кореляційного аналізу показано, що навчальне середовище впливає на досягнення школярами предметних освітніх результатів, перш за все, за рахунок своєї інтенсивності, а також за рахунок зовнішніх факторів, обумовлених взаємодією школи з соціальним середовищем, в той час як внутрішні фактори, пов'язані $з$ психологічним кліматом у школі, не мають суттєвого значення.

Інструментом побудови якісної освітньої моделі є моніторинг якості освіти, головним складником якого є моніторинг рейтингових оцінок учнів. Сучасна практика проведення таких досліджень характеризується відсутністю комплексної моделі моніторингу якості освіти студента чи учня, яка б дозволяла систематично, прозоро та ефективно відслідковувати динаміку результатів навчання, встановлювати причини проблем і розробляти прогноз. Запропонована нами робота присвячена дослідженню статистичними методами навчальних оцінок (рейтингових оцінок). 


\section{Mathematical modelling of quality education monitoring}

\section{3. Кореляційний аналіз навчального процесу}

Відомо, що рівень знань учня з одного навчального предмету певним чином впливає на рівень знань з іншого предмету. Наприклад, не знаючи елементарних алгебраїчних перетворень і методів розв'язування рівнянь, неможливо розв'язати задачі з фізики та хімії. Не знаючи рідної мови, загальних правил правопису, синтаксису, складно вивчати іноземні мови. Вагомість та напрям зв'язків в знаннях учнів допомагає визначити коефіцієнт кореляції. Проблема полягає в тому, що на сьогоднішній день для величин, визначених в абсолютній формі, таких як вага, відстань, вартість, та величин, визначених за допомогою експертних оцінок, а саме, в нашому випадку, оцінок викладачів, існують різні коефіцієнти кореляції. Саме висвітленню цих аспектів кореляційного аналізу і присвячено запропонований розділ роботи $[8$, c. $146 ; 9$, с. $136 ; 10$, c. 248$]$.

Як правило, для дослідження взаємозв'язків між різними випадковими величинами, зокрема оцінками учнів з різних предметів, використовується апарат коефіцієнтів парної кореляції. Але часто закон розподілу цих випадкових величин є невідомим і тому обчислення таких коефіцієнтів не завжди $є$ коректним. Саме тому нами запропоновано застосовувати коефіцієнти кореляції Спірмена, які не залежать від розподілу вибірки. Обчислювати ці коефіцієнти доцільніше із застосуванням зв'язаних рангів, що є суттєво складнішим, ніж обчислення цих же коефіцієнтів із незв'язаними рангами.

Кореляційний аналіз має на меті визначити кількісну міру статистичного зв' язку між двома ознаками. Він не встановлює причин залежності між досліджуваними ознаками, а лише виявляє наявність самої залежності, її величину та напрям. Отже, метод кореляційного аналізу вирішує наступні завдання: 1) взаємозв'язок (чи є взаємозв'язок між ознаками?); 2) непряме здобуття інформації (якщо $є$ відомою поведінка одного параметру, та відомо, що другий параметр з ним корелює, то є відомою і поведінка другого параметру); 3) класифікація та ідентифікація об'єктів (кореляційний аналіз допомагає підібрати набір незалежних ознак для класифікації об'єктів).

Рангова кореляція. Для обробки даних соціологічних досліджень (анкет), рейтингів, експертних оцінок тощо, часто застосовують методи рангової кореляції (тобто там, де ознаки вимірюються за допомогою номінальної або порядкової шкали). Найчастіше застосо- 
вують коефіцієнти рангової кореляції Спірмена та Кендалла. Коефіцієнт Спірмена більш точно враховує саме кількісний ступінь зв'язку між змінними. Порівняльна оцінка коефіцієнтів рангової кореляції Спірмена та Кендалла показує, що обчислення коефіцієнтів Спірмена проводиться за більш простою формулою. Крім того, коефіцієнт Спірмена дає більш точний результат, оскільки він $є$ оптимальною (за критерієм мінімуму середнього квадрата похибки) оцінкою коефіцієнта кореляції.

Дослідження проводиться виходячи з припущення, що усі спостереження взаємно незалежні, усі значення спостережень взяті з однієї і тієї ж двовимірної генеральної сукупності, тобто вважаємо, що X та Y однаково розподілені.

Визначення коефіцієнту рангової кореляції Спірмена відноситься до непараметричного методу, який застосовується з метою статистичного вивчення зв'язку між явищами. Цей коефіцієнт фактично визначає ступінь паралелелізму між двома кількісними рядами ознак, що вивчаються, а також кількісну оцінку щільності встановленого зв'язку. Аналізуючи коефіцієнти як парної кореляції, так і кореляції Спірмена, слід пам'ятати, що кореляція не є показником залежності одного фактору від іншого, а лише встановлює їх сумісну варіативність. Якщо дві ознаки змінюються узгоджено, то це може означати, що має місце ще і якийсь третій фактор, що впливає на ці дві ознаки. Якщо значення ознак співпадають, то ранг визначається шляхом ділення суми рангів на число значень. У цьому випадку кажуть, що є зв'язані ранги. Загалом, ранжування призводить до того, що значення рядів мають однаковий мінімум рівний 1 і максимум, рівний кількості значень (тобто кількості елементів вибірки).

При застосуванні коефіцієнта рангової кореляції Спірмена ( $\rho$ ) умовно оцінюють щільність зв'язку між ознаками за шкалою Чеддока [11, с. 159] (таблиця 1).

Таблиця 1

Градація щільності зв'язку між явищами

\begin{tabular}{|l|c|c|c|c|c|}
\hline & \multicolumn{2}{|c|}{ Середній } & & \multicolumn{2}{c|}{ Сильний } \\
\hline $\begin{array}{l}\text { Характеристики } \\
\text { щільності зв'язку }\end{array}$ & Слабкий & Помірний & Помітний & Високий & $\begin{array}{c}\text { Дуже } \\
\text { високий }\end{array}$ \\
\hline $\begin{array}{l}\text { Величина коефі- } \\
\text { цієнта кореляції }\end{array}$ & $0,1-0,3$ & $0,3-0,5$ & $0,5-0,7$ & $0,7-0,9$ & $0,9-1,0$ \\
\hline
\end{tabular}


Коефіцієнт кореляції рангів Спірмена [1, с. 447; 12, с. 211] визначається за формулою

$$
\rho=1-\frac{6 \sum_{i=1}^{n}\left(r_{i}-s_{i}\right)^{2}}{n^{3}-n},
$$

де $r_{i}$ та $s_{i}$-ранги $i$ - того об'єкта по змінним $X, Y, n$ - число пар спостережень. Значення коефіцієнтів кореляції рангів Спірмена також коливаються від «-1» до «+1». Чим ближчими є значення коефіцієнта до 1, тим тіснішим є зв'язок. Знаки «+» або «-» вказують напрям зв'язку. Якщо ранги за обома ознаками співпадають, то зв'язок прямий, тобто $r_{i}=1$. Якщо $r_{i}=0$, то зв'язок між ознаками відсутній.

При ранжуванні інколи бувають випадки, коли неможливо знайти істотні відмінності між об'єктами за величиною прояву ознаки. У такому випадку об'єкти називають зв'язаними. Таким об'єктам приписують однакові середні ранги, такі, щоб сума усіх рангів залишалась такою ж, як і при відсутності зв’язаних рангів.

При наявності зв'язаних рангів ранговий коефіцієнт кореляції Спірмена обчислюють за формулою [1, с. 447]:

$$
\rho=1-\frac{\sum_{i=1}^{n}\left(r_{i}-s_{i}\right)^{2}}{\frac{1}{6}\left(n^{3}-n\right)-\left(T_{r}+T_{s}\right)},
$$

де $T_{r}=\frac{1}{12} \sum_{i=1}^{m_{r}}\left(t_{r}^{3}-t_{r}\right) T_{r}=\frac{1}{12} \sum_{i=1}^{m_{s}}\left(t_{s}^{3}-t_{s}\right), m_{r}, m_{s}-$ число груп однакових рангів у змінних $X$ та $Y ; t_{r}, t_{s}$ - число рангів, які входять у групу однакових рангів змінних $X$ та $Y$.

В таблиці 2 представлено коефіцієнти кореляції Спірмена між річними оцінками з 16 навчальних предметів усіх учнів 9-г класу (фізико-математичний ліцей № 145, м. Київ, 2010 рік).

В таблиці 2 прийняті наступні умовні позначення: П- предмети (1 - українська мова, 2 - українська література, 3 - зарубіжна література, 4 - англійська мова, 5 - алгебра, 6 - геометрія, 7 - основи інформатики та обчислювальної техніки, 8 - історія України, 9 - всесвітня історія, 10 - географія, 11 - правознавство, 12 - біологія, 13 - фізика, 14 - хімія, 15 - фізичний практикум, 16 - художня культура).

Проаналізувавши кореляційну матрицю (таблиця 2), отримуємо зовсім неочікуваний результат. Здавалося б, гуманітарна група пред- 
метів повинна мати сильні взаємозв'язки між собою, але значення відповідних коефіцієнтів кореляції не перевищують 0,62 . Дивним $\epsilon$ те, що оцінки з зарубіжної літератури мають слабкий зв'язок з оцінками 3 української літератури, що не піддається стандартній логіці.

Таблиця 2

Кореляційна матриця річних оцінок учнів

\begin{tabular}{|c|c|c|c|c|c|c|c|c|c|c|c|c|c|c|c|c|}
\hline$\Pi$ & 1 & 2 & 3 & 4 & 5 & 6 & 7 & 8 & 9 & 10 & 11 & 12 & 13 & 14 & 15 & 16 \\
\hline 1 & 1,0 & 0,57 & 0,63 & 0,42 & 0,56 & 0,58 & 0,55 & 0,52 & 0,43 & 0,62 & 0,26 & 0,47 & 0,43 & 0,32 & 0,46 & 0,26 \\
\hline 2 & & 1,0 & 0,37 & 0,46 & 0,6 & 0,55 & 0,53 & 0,6 & 0,62 & 0,58 & 0,47 & 0,6 & 0,41 & 0,26 & 0,51 & 0,13 \\
\hline 3 & & & 1,0 & 0,04 & 0,38 & 0,49 & 0,53 & 0,51 & 0,29 & 0,41 & 0,37 & 0,52 & 0,2 & 0,34 & 0,54 & 0,48 \\
\hline 4 & & & & 1,0 & 0,59 & 0,53 & 0,28 & 0,31 & 0,4 & 0,19 & 0,24 & 0,4 & 0,54 & 0,27 & 0,25 & $-0,2$ \\
\hline 5 & & & & & 1,0 & 0,9 & 0,7 & 0,53 & 0,46 & 0,37 & 0,37 & 0,56 & 0,62 & 0,49 & 0,55 & 0,22 \\
\hline 6 & & & & & & 1,0 & 0,73 & 0,46 & 0,36 & 0,34 & 0,34 & 0,57 & 0,58 & 0,49 & 0,5 & 0,24 \\
\hline 7 & & & & & & & 1,0 & 0,68 & 0,46 & 0,44 & 0,58 & 0,61 & 0,52 & 0,51 & 0,49 & 0,3 \\
\hline 8 & & & & & & & & 1,0 & 0,85 & 0,68 & 0,81 & 0,79 & 0,6 & 0,38 & 0,58 & 0,33 \\
\hline 9 & & & & & & & & & 1,0 & 0,61 & 0,73 & 0,63 & 0,6 & 0,42 & 0,5 & 0,06 \\
\hline 10 & & & & & & & & & & 1,0 & 0,4 & 0,54 & 0,38 & 0,25 & 0,43 & 0,42 \\
\hline 11 & & & & & & & & & & & 1,0 & 0,62 & 0,54 & 0,46 & 0,43 & 0,1 \\
\hline 12 & & & & & & & & & & & 1,0 & 0,69 & 0,37 & 0,46 & 0,39 \\
\hline 13 & & & & & & & & & & & & & 1,0 & 0,33 & 0,45 & 0,01 \\
\hline 14 & & & & & & & & & & & & & & 1,0 & 0,29 & 0,29 \\
\hline 15 & & & & & & & & & & & & & & & 1,0 & 0,06 \\
\hline 16 & & & & & & & & & & & & & & & & 1,0 \\
\hline
\end{tabular}

Це свідчить про вплив на навчання з цих предметів якихось додаткових факторів або про неузгодженість системи оцінювання вчителями рівня знань учнів, чого не має бути 3 логічно пов'язаними предметами. Можна зробити висновок, що дана ситуація потребує додаткової уваги - в ній є що покращувати.

Далі, проаналізувавши групу природничих наук, таких як хімія, фізика, біологія, знову отримуємо зовсім неочікувані результати. Здавалось би, що кореляційний зв'язок між цими дисциплінами має бути досить високим (на рівні 0,7-0,9). Насправді ж, спостерігаємо таке: коефіцієнт кореляції Спірмена у всієї сукупності коливається від 0,37 до 0,69, що, можливо, пов'язано з тим, що в 9 класі були відсутні підручники з хімії, і весь навчальний матеріал зберігався лише у конспекті. 
Найтіснішим є зв'язок між алгеброю, геометрією та основами інформатики та обчислювальної техніки, що свідчить про узгодженість критеріїв оцінювання вчителями 3 цих навчальних дисциплін, а також про те, що учень 3 поганим рівнем знань $з$ одного із цих предметів не має хороший рівень знань з інших предметів.

Також розділивши кореляційну матрицю успішності учнів, відокремивши дівчат та хлопців, можна встановити вплив гендерних аспектів на успішність учнів. У підсумку проведені дослідження показали, що присутня слаба корельованість успішності всередині блоків гуманітарних і природничих дисциплін, мають місце від'ємні коефіцієнти кореляції, наприклад, між українською та англійською мовами, зарубіжною літературою та всесвітньою історією, а це вже свідчить про неузгодженість вимог викладачів до рівня знань учнів, що є недопустимим у будь-якому навчальному закладі. Такий фактор як «стать» має відчутний вплив на успішність 3 певних навчальних дисциплін. Виявлені недоліки у навчальному процесі свідчать про дію деяких зовнішніх факторів (що не залежать від учнів) на сам навчальний процес. Запропонований метод аналізу, математичний апарат і технічні засоби можуть бути використані для аналізу навчальних процесів вузів та навчальних закладів з різним рівнем акредитації.

\section{4. Порівняльно-статистичний аналіз результатів навчального оцінювання}

Багаторічна практика викладання курсу вищої математики на факультеті соціології та прав НТУУ «КПІ імені Ігоря Сікорського» показала, що проблеми з вивченням математики у студентів закладено ще у процесі вивчення елементарної математики в школі, і сприяє цьому в значній мірі неадекватність оцінювання рівня знань 3 математики ще на рівні шкільного атестату. Також неадекватність оцінювання має місце при зовнішньому незалежному оцінюванні (ЗНО). Про це яскраво свідчать наступні статистичні дані (отримані у вересні 2013 року в результаті проведення вхідного контролю з елементарної математики). Наприклад, показовою є кореляційна матриця (таблиця 3), складена на основі оцінок студентів - соціологів з алгебри та геометрії в шкільному атестаті (зараз при вступі на факультет соціології та права студенти не складають ЗНО з математики) та контрольної роботи з збереження знань (КРЗ3) 3 елементарної математики, що була проведена в НТУУ «КПІ». 
Seleznova Nadiia, Rudyk Tetyana

Таблиця 3

Кореляційна матриця оцінок студентів соціологів

\begin{tabular}{|c|c|c|c|}
\hline предмети & алгебра & геометрія & КР33 \\
\hline алгебра & 1 & 0,951 & 0,346 \\
\hline геометрія & & 1 & 0,230 \\
\hline КР33 & & & 1 \\
\hline
\end{tabular}

Як бачимо, коефіцієнт кореляції між оцінками, отриманими в школі та на вхідному контролі в НТУУ «КПІ» є досить низьким, що вказує на невідповідність вимог до рівня знань 3 математики в школі та в КПІ.

В таблиці 4 представимо наступні показники: Сер. бал. $(\bar{x})-$ середній бал, отриманий студентом з математики в шкільному атестаті за 12-бальною шкалою; Sigma $(\sigma)$ - середньоквадратичне відхилення; Var - коефіцієнт варіації: Var $=\frac{\sigma}{\bar{x}} 100$. Коефіцієнт варіації визначається у відсотках і показує, як коливається ознака у сукупності [13, с. 28]. Як видно $з$ таблиці 4, маємо дуже високий показник варіації з КРЗ3, що свідчить про велику різницю у рівні знань з елементарної математики у студентів (КР33 - оцінювалось за 100-бальною шкалою). Суттєво великі значення коефіціснтів Asimetria та Ekscess також свідчать про суттєву неоднорідність та скошеність оцінок із КРЗ3.

Таблиця 4

Основні точкові показники студентів соціологів

\begin{tabular}{|c|c|c|}
\hline & математика & KP33 \\
\hline Сер. бал & 8,613 & 9,675 \\
\hline Sigma & 1,512 & 16,417 \\
\hline Var & 17,560 & 169,685 \\
\hline Moda & 8 & 0 \\
\hline Mediana & 8 & 0 \\
\hline Asimetria & $-0,153$ & 2,866 \\
\hline Ekscess & 0,151 & 10,312 \\
\hline
\end{tabular}

Для порівняння розглянемо оцінки студентів I курсу з механіко-машинобудівного факультету НТУУ «КПІ», які, на відміну від соціологів, складали $3 \mathrm{HO}$ з математики.

На рис. 1 представлено розподіл оцінок з курсу шкільної математики (за 12-бальною системою) за даними шкільних атестатів студентів механіків (20 осіб) та соціологів (40 осіб). 
Mathematical modelling of quality education monitoring

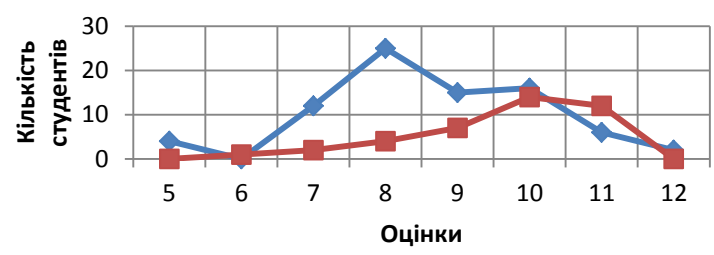

- Математикаатестат(соціологи)

- Математика-атестат (механіки)

\section{Рис. 1. Розподіл оцінок з курсу шкільної математики студентів механіків та соціологів}

Як бачимо з рис. 1, оцінки студентів соціологів з курсу шкільної математики є доволі високими при реально низьких знаннях, як засвідчує КРЗ3. Оцінки механіків у шкільному атестаті є нижчими, ніж оцінки соціологів, і у той же час, як засвідчує КРЗ3, знання з математики є суттєво кращими.

В таблиці 5 представлено кореляційну матрицю оцінок студентів механіків з алгебри, геометрії (шкільний атестат) та ЗНО і КРЗЗ. Коефіцієнти кореляції між оцінками з шкільного атестату, та КРЗ3 є хоч і низькими, але при цьому вищими, ніж у соціологів.

В таблиці 6 представлено показники аналогічні таблиці 4 для студентів механіків.

Таблиця 5

Кореляційна матриця оцінок студентів механіків

\begin{tabular}{|c|c|c|c|c|}
\hline & алгебра & геометрія & 3НО & КР33 \\
\hline алгебра & 1 & 0,775 & 0,578 & 0,455 \\
\hline геометрія & & 1 & 0,496 & 0,428 \\
\hline ЗНО & & & 1 & 0,585 \\
\hline
\end{tabular}

При порівнянні показників таблиць 4 та 6 видно, що коефіцієнт варіації з КРЗ3 для студентів механіків є досить високим, але більш ніж вдвічі меншим, ніж аналогічний показник у соціологів. 3 проведеного аналізу можна зробити висновок, що оцінки, отримані студентами з математики в шкільних атестатах не відповідають рівню знань цих студентів.

Загалом, проведений статистичний аналіз оцінок досить об'єктивно вказує на великі проблеми з рівнем викладання математики в Україні. 
Seleznova Nadiia, Rudyk Tetyana

Таблиця 6

Основні точкові показники студентів механіків

\begin{tabular}{|c|c|c|c|}
\hline & математика & КР33 & 3НО \\
\hline Ceр. бал & 9,675 & 26,350 & 178,050 \\
\hline Sigma & 1,273 & 19,893 & 9,546 \\
\hline Var & 13,153 & 75,495 & 5,361 \\
\hline Moda & 10 & - & 183 \\
\hline Mediana & 10 & 18,500 & 181 \\
\hline Asimetria & $-1,015$ & 0,778 & $-0,665$ \\
\hline Ekscess & 0,602 & $-0,340$ & 0,071 \\
\hline
\end{tabular}

\section{5. Аналіз моніторингу якості освіти за показником нестабільності}

Моніторинг якості освіти також можна проводити за показником аналізу емпіричних даних - показником нестабільності [14, с. 185], під яким розуміють міру їхнього варіювання (коливання), а під стабільністю - розуміють протилежне поняття.

Стабільність $\epsilon$ важливою характеристикою в аналізі експертних оцінок, а, отже, і навчальних оцінок.

Мірою стабільності чи нестабільності служить відношення стандартного відхилення ряду даних, виміряних в певній шкалі, до половини бази шкали:

$$
S t=\frac{\sigma_{x}}{\Delta_{x}} \text {, де } \sigma_{x}^{2}=\frac{1}{S} \sum_{i=1}^{s} X_{i}^{2}-M_{x}^{2}, M_{x}=\sum_{i=1}^{s} X_{i}, \Delta_{x}=0,5\left(X_{\max }-X_{\min }\right),
$$

де $s$ - кількість даних. Завдяки тому, що $0 \leq \sigma_{x} \leq \Delta_{x}$, маємо $0 \leq S t \leq 1$. Отже, маємо найбільшу стабільність при $S t=0$, та найбільшу нестабільність при $S t=1$.

Виходячи з оцінок, отриманих студентами на сесії з чотирьох предметів $A, B, C, D$ (факультет соціології та права, 1 курс, НТУУ «КПІ імені Ігоря Сікорського»), обчислимо середні значення $M_{x}$, дисперсії $D$ та показника стабільності St $[15$, с. 326]. Результати занесено до таблиці 7.

Таблиця 7

Точкові показники та показники стабільності оцінок успішності

\begin{tabular}{|c|c|c|c|c|c|}
\hline & A & B & C & D & ABCD \\
\hline$M_{x}$ & 3,955 & 3,932 & 4,614 & 3,795 & 4,074 \\
\hline$D$ & 0,816 & 1,018 & 0,646 & 1,026 & 0,977 \\
\hline$S t$ & 0,544 & 0,679 & 0,431 & 0,684 & 0,652 \\
\hline
\end{tabular}


В таблиці 7 під $A B C D$ розуміємо загальні показники по всім чотирьом предметам. Отримані значення $S t$ свідчать про значну нестабільність успішності даної групи студентів по кожному предмету окремо і по всім предметам загалом. Інформативним $\epsilon$ порівняння показників нестабільності з середнім балом та дисперсією.

Перевіримо гіпотезу про однаковість чи відмінність чотирьох вибірок за показниками нестабільності (результатів складання студентами іспитів під час сесії по чотирьом предметам A,B,C,D) з метою встановити, чи не відносяться вони до однієї сукупності, або чи не підлягають вони певним змінам в залежності від змін певних умов. Для цього застосуємо $G$ - критерій: $G_{E}=D_{\max } / \sum_{i=1}^{m} D_{i}$, де $D_{\max }-$ найбільша із дисперсій, які порівнюємо, $m$ - число дисперсій, $1-\alpha$ - довірча ймовірність гіпотези, про те, що дисперсії відрізняються, $v$ - число елементів у вибірці (використовується при знаходженні критичного значення за таблицею 7) $\left[16\right.$, с. 186]. У нашому прикладі: $G_{E}=0,684 / 3,507=0,195 . G_{\text {крит }}$ знайдемо за таблицею квантилів розподілу $G$ - критерію: $G_{\text {крит }}=0,36$, при $1-\alpha=0,95, \quad m=4, \quad v=44 . G_{E}=0,195<G_{\text {крит }}=0,36$. Отже, дисперсії $\epsilon$ однорідними і вибірки можна вважати статистично однорідними, такими, що відносяться до однієї сукупності. В цілому можна зробити висновок, що різниця нестабільності рядів оцінок статистично є незначною.

\section{6. Моніторинг якості освіти та контент аналіз}

Якість освіти також залежить від якості проведення тестування учнів з різних предметів. В нашій країні на сьогоднішній день одним із способів вимірювання якості шкільної освіти $є$ проведення ЗНО 3 різних навчальних дисциплін. Одним із способів визначення якості самих тестових завдань ЗНО є контент-аналіз цих тестів.

Контент-аналізом називається аналіз змісту (англ. "contents" - зміст, вміст, склад). Предметом такого аналізу є зміст текстових масивів. Також він визначається як кількісний аналіз текстів та текстових масивів 3 метою наступної змістовної інтерпретації виявлених числових закономірностей. За допомогою контент-аналізу можна здійснити повний цикл дослідження будь-якого документального об'єкта. Цей вид аналізу суттєво відрізняється від інших методів дослідження документів і має самостійний шлях наукового дослідження [16, с. 131; 10, с. 248]. Кількісний контент-аналіз базується на дослідженні слів, тем, повідомлень. При 
цьому основна увага зосереджується на змісті тексту. Отже, аналізуючи елементи тексту, в першу чергу необхідно скласти певний тезаурус, в якому кожне окреме спостереження матиме визначення і буде віднесено до певного класу. Тобто на базі виділених класів формується вибірка, що складається із тих типів ключових понять, сповіщень, означень, понять, які з найбільшою ймовірністю зустрічаються в досліджуваному тексті. Елементи цієї вибірки є деякими смисловими одиницями, які можна позначити певними числами. Тоді на базі цих чисел можна скласти варіаційний ряд, який вже можна досліджувати статистичними методами.

Нами проведено контент-аналіз завдань ЗНО з математики за 2009, 2013 та 2016 роки 3 метою дослідження структури завдань [10, с. 249]. Для початку виділимо основні теми, згідно яких складено завдання ЗНО. Перелік тем: 1) дійсні числа, порівняння чисел та дії з ними; числові множини; 2) відношення та пропорції, відсотки; 3) текстові задачі; 4) раціональні, ірраціональні, степеневі, показникові, логарифмічні, тригонометричні вирази та їхні перетворення; 5) лінійні, квадратні, раціональні, ірраціональні, показникові, логарифмічні рівняння, нерівності та їхні системи; 6) числові послідовності: арифметична та геометрична прогреciї; 7) функціональна залежність, властивості функції, графіки елементарних функцій; 8) похідна функції, іiі геометричний та фізичний зміст; 9) первісна та визначений інтеграл; застосування визначеного інтеграла до обчислення площ плоских фігур; 10) елементи комбінаторики; ймовірність випадкової події; 11) коло та круг; 12) основні задачі планіметрії; трикутники, чотирикутники, багатокутники; 13) прямі та площини у просторі; 14) елементи векторної алгебри; декартова система координат; 15) многогранники, тіла й поверхні обертання; 16) задачі з параметрами.

Визначивши кількості (частоти) завдань, згідно названих тем, побудуємо гістограму (рис. 2) по відповідних роках та обчислимо деякі статистичні показники, які представимо у вигляді таблиці 8.

Таблиця 8

\section{Статистичні показники}

\begin{tabular}{|l|c|c|c|}
\hline Статистичні показники & $\mathbf{2 0 0 9}$ рік & $\mathbf{2 0 1 3}$ рік & $\mathbf{2 0 1 6}$ рік \\
\hline Мода & 4,5 & 7 & 4,7 \\
\hline Варіація & $58,5 \%$ & $52,1 \%$ & $51,9 \%$ \\
\hline Ентропія & 3,33 & 3,29 & 3,65 \\
\hline Надлишок інформації & 0,32 & 0,35 & 0,27 \\
\hline
\end{tabular}




\section{Mathematical modelling of quality education monitoring}

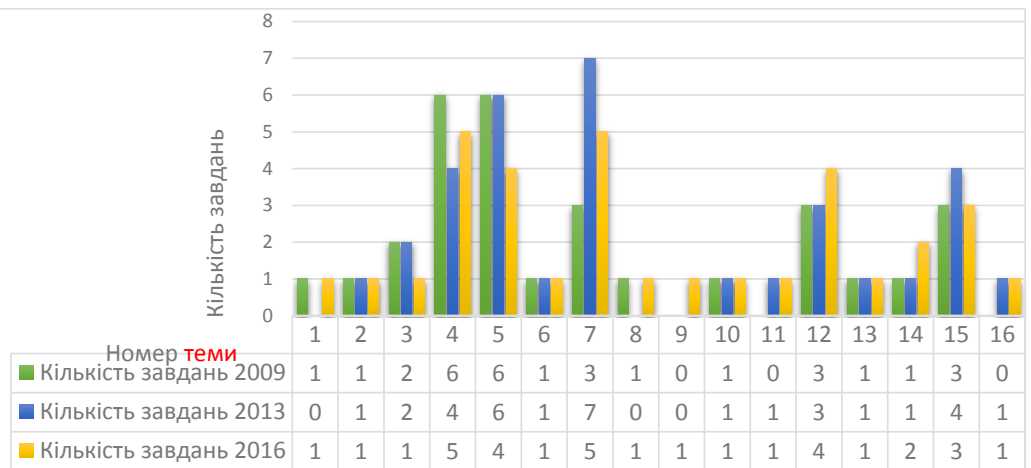

\section{Рис. 2. Частотна гістограма завдань}

Суть деяких понять, згаданих у таблиці 8. Означення ентропії $[17$, с. 104] : нехай $U$ - деякий дослід, який може мати $n$ різних результатів $A_{1}, A_{2}, \ldots, A_{n}$ з ймовірностями $P\left(A_{1}\right), P\left(A_{2}\right), \ldots, P\left(A_{n}\right)$; $B$ - інший дослід, що має результати $B_{1}, \mathrm{~B}_{2}, \ldots, \mathrm{B}_{n} 3$ ймовірностями $P\left(\mathrm{~B}_{1}\right), P\left(\mathrm{~B}_{2}\right), \ldots, P\left(\mathrm{~B}_{n}\right)$. Якщо через $P\left(A_{i} B_{k}\right)$ позначити ймовірність суміщення результатів дослідів $U$ та $B$, то згідно Шеннону [12, с. 249; 17, с. 104] середня кількість інформації, що міститься в результатах досліду $U$ відносно результатів досліду $B$ обчислюється за формулою $I(U, B)=\sum P\left(A_{i} B_{k}\right) \log _{2} \frac{P\left(A_{i} B_{k}\right)}{P\left(A_{i}\right) P\left(B_{k}\right)}$.

Кількість інформації, що міститься в результатах досліду $U$ відносно самого себе (тобто повна кількість інформації, що міститься в результатах досліду $U$ ), називається ентропією і обчислюється за формулою: $H=-\sum P\left(A_{i}\right) \log _{2} P\left(A_{i}\right)$. Всі можливі значення ентропії містяться у проміжку: $0 \leq H(X) \leq \log _{2} N$ (у нашому випадку: $\log _{2} 30=4,91$; $\log _{2} 33=5,04$, для 2009 р. $-N=30$, для 2013 та 2016 років $N=33$. Нижня грань відповідає виродженому розподілу. В цьому випадку невизначеність $є$ відсутньою. У варіаційному ряду це відповідає $x_{i}=$ const. Верхня межа відповідає рівномірному розподілу. В цьому випадку всі $N$ значень $x_{i}$ зустрічаються 3 однаковою ймовірністю. У варіаційному ряду це відповідає лінійному тренду. Чим меншою $є$ ймовірність якоїсь події, тим більшу невизначеність має звістка про іiі появу, і отже, тим більшу інформацію вона несе. 
Надлишковість інформації оцінюється коефіцієнтом надлишку інформації: $R=1-\frac{H(X)}{H_{\max }}$. Наявність надлишку означає, що частину сповіщень можна і не передавати по каналу зв'язку, а поновити за відомими статистичними зв'язками. Але при збільшені надлишку є можливість зменшення похибок передачі інформації і при цьому з'являється кілька варіантів розвитку системи.

В таблиці 8 представлено обчислені показники ентропії та надлишку інформації для тестів ЗНО за різні роки. Величина ентропії за різні роки не суттєво відрізняється, отже можна вважати, що розподіли частот різних завдань за ці роки практично не відрізняються одне від одного, а надлишок інформації вказує, що залишаючись в межах того ж розподілу, можна моделювати різні інші варіанти тестових завдань.

Коефіцієнти варіації (відношення середньоквадратичного відхилення до середнього значення, визначається у відсотках) вказують у нашому випадку на помірну неоднорідність тестових завдань. Із значення моди можна зробити висновки відносно того, які теми тестових завдань найчастіше є присутніми в ЗНО.

Так як рівень знань та навичок випускників шкіл оцінюється результатом складання 3НО, то і вчителі в процесі викладання математики в школі орієнтуються на підготовку учнів до успішного складання ЗНО. В результаті такі важливі у вищому навчальному закладі теми, як числові послідовності, похідна, елементи інтегрального числення, комбінаторика, елементи теорії ймовірностей, вкрай необхідні для засвоєння курсу вищої математики, залишаються поза увагою шкільних вчителів. В результаті це суттєво знижує рівень математичної підготовки абітурієнтів, а відтак і студентів, з огляду на те, що у вищих навчальних закладах за останні роки відбулось суттєве скорочення годин для вивчення математики.

\section{7. Висновки}

В роботі представлено новий підхід до розв'язання задач моніторингу освітнього процесу, заснований на стохастичних моделях, який суттєво відрізняється від загальновідомих методів. За об'єкт дослідження взято навчальні оцінки шкільних вчителів, оцінки групи студентів-першокурсників Київського політехнічного інституту імені Ігоря Сікорського, отримані ними в процесі навчання та їх оцінки в шкільних атестатах та ЗНО. 
В даній публікації представлено підбірку матеріалів, опублікованих авторами, протягом останніх років, присвячену кореляційному та статистичному аналізу узгодженості навчальних оцінок.

Аналізуючи кореляційні матриці успішності учнів, проведено факторний аналіз шляхом об'єднання оцінок з предметів у певні групи за змістом предметів та за гендерною ознакою. Проведено аналіз елементів кореляційної матриці успішності учнів та виявлено неузгодженості вимог викладачів до оцінювання учнів.

Також було проведено за допомогою кореляційного аналізу та статистичних точкових оцінок порівняння результатів успішності 3 математики студентів першого курсу двох факультетів ВН3 із результатами ЗНО та вхідного контролю зі збереження знань 3 математики. Результати показали, що шкільні оцінки студентів першого факультету значно вищі за оцінки студентів другого і в той же час оцінки вхідного контролю засвідчили значно кращі результати з математики у студентів другого факультету. Все це свідчить про певну неадекватність в оцінюванні знань учнів з математики у школі. Також обчислено показники ентропії та нестабільності навчальних оцінок.

Методом контент аналізу проведено аналіз якості складання тестових завдань на прикладі завдань ЗНО. Результати проведених досліджень можуть суттєво допомогти у висвітленні як недоліків навчального процесу так і його успішні аспекти.

Надалі перспективним напрямком є застосування методів регресійного аналізу до навчальних оцінок.

\section{Список літератури:}

1. Кремер Н.Ш.(2006). Теория вероятностей и математическая статистика, М.: ЮНИТИ: 573 с.

2. Гнатієнко Г.М., Снитюк В.С. (2008). Експертні технології прийняття рішень, К.: ТОВ Маклаут : 444 с.

3. Harti R.E. (1990). A global convegece proof for class of genetic algorithms. Technische Universitaet Wien : $136 \mathrm{p}$.

4. Моніторинг якості освіти: світові досягнення та українські перспективи ( за заг. ред. О.І. Локшиної ) (2004), К.: К.І.С.: 128 с.

5. Шишов С.Е., Кальней В.А. (1998). Мониторинг качества образования в школе, М.: Росийское педагогическое агентство: 35 с.

6. Моніторинг якості освіти: становлення та розвиток в Україні: Рекомендації з освітньої політики (за заг. ред. О.І. Локшиної) (2004), К.: К.І.С.: $160 \mathrm{c}$. 
7. Шишов С.Е., Кальней В.А. (1999). Мониторинг качества образования в школе, М.: Педагогическое общество России: 320 с.

8. Селезньова Н.П., Українець О.В. (2016). Моніторинг якості освіти через призму кореляційного аналізу. Сімнадцята міжнародна наукова конференція імені академіка М. Кравчука, 19-20 травня Київ. Матеріали конференції, 3 (1). Теорія ймовірностей та математична статистика. Історія та методика математики, К.: НТУУ «КПІ»: с. 146-149.

9. Селезньова Н.П., Селезньова Н.В., Селезньов С.В. (2012). Кореляційний аналіз навчального процесу на прикладі підсумкових оцінок учнів. Вісник НТУУ «КПІ» 1, Філософія, психологія, педагогіка, К.: с. 136-138.

10. Селезньова Н.П., Селезньов С.В. (2016). Контент-аналіз якості ЗНО 3 математики. Математика в сучасному технічному університеті: матеріали V Міжнародна науково-практична конференція (Київ, 29-30 грудня 2016 р.), Київ: НТУУ «КПІ»: с. 248-251.

11. Мазуренко В.П. (2006). Статистика, К.: «Київський університет»: 315 с.

12. Spearman S. (1904). General intelligence objectwely determined and measured. American Journal of Psychology, 15: p. 201-293.

13. Селезньова Н.В., Селезньова Н.П., Рудик Т.О. (2012). Завдання та методичні вказівки для самостійної роботи з основ теорії ймовірностей, Київ: 70 с.

14. Суходольський Г.В. (2007). Математика для гуманитариев, Харьков: Гуманитарный центр: 256 с.

15. Селезньова Н.В., Селезньова Н.П. (2013). Специфіка викладання математичної статистики для соціологів 3 використанням сучасних комп'ютерних технологій. Міжнародна науково-практична конференція «Математика в сучасному технічному університеті», 19-20 квітня Київ, К.: НТУУ «КПІ»: c. 324-327.

16. Алексеев А.Н. (1974). Контент-анализ, его задачи, объекты и средства. Социология культуры, 1: с. 131-162.

17. Селезньова Н.П., Селезньова Н.В.(2010). Ентропійний підхід до визначення узгодженості експертних оцінок. XIII Міжнародна наукова-практична конференція імені академіка М. Кравчука, 13-15 травня Київ. Матеріали конференції, 3, К.: с. 104.

\section{References:}

1. Kremer N.Sh. (2006). Teoriya veroyatnostey i matematicheskaya statistika [Theory of Probability and Mathematical Statistics], M.: YuNITI: 573 s. (in Russian)

2. Hnatiienko H.M., Snytiuk V.Ye. (2008). Ekspertni tekhnolohii pryiniattia rishen [Expert decision making technologies], K.: TOV Maklaut : $444 \mathrm{~s}$. (in Ukrainian)

3. Harti R.E. (1990). A global convegece proof for class of genetic algorithms. Technische Universitaet Wien : $136 \mathrm{p}$.

4. Monitorynh yakosti osvity: svitovi dosiahnennia ta ukrainski perspektyvy [Monitoring the quality of education: world achievements and Ukrainian perspectives] (za zah. red. O.I. Lokshynoi) (2004), K.: K.I.S.: 128 s. (in Ukrainian) 
5. Shishov S.E.,Kal'ney V.A. (1998). Monitoring kachestva obrazovaniya v shkole [Monitoring the quality of education in school], M.: Rosiyskoe pedagogicheskoe agentstvo: 35 s. (in Russian)

6. Monitorynh yakosti osvity: stanovlennia ta rozvytok v Ukraini: Rekomendatsii z osvitnoi polityky [Monitoring quality of education: establishment and development in Ukraine: educational policy recommendations] (za zah. red. O.I. Lokshynoi) (2004), K.: K.I.S.:160 s. (in Ukrainian)

7. Shishov S.E., Kal'ney V.A. (1999). Monitoring kachestva obrazovaniya v shkole [Monitoring the quality of education in school], M.: Pedagogicheskoe obshchestvo Rossii: 320 s. (in Russian)

8. Seleznova N.P., Ukrainets O.V. (2016). Monitorynh yakosti osvity cherez pryzmu koreliatsiinoho analizu [Monitoring the quality of education through the prism of correlation analysis]. Simnadtsiata mizhnarodna naukova konferentsiia imeni akademika M. Kravchuka, 19-20 travnia Kyiv. Materialy konferentsii, 3 (1). Teoriia ymovirnostei ta matematychna statystyka. Istoriia ta metodyka matematyky, K.: NTUU "KPI": s. 146-149.

9. Seleznova N.P., Seleznova N.V., Seleznov S.V. (2012). Koreliatsiinyi analiz navchalnoho protsesu na prykladi pidsumkovykh otsinok uchniv [Correlation analysis of the educational process on the example of the final marks of students]. Visnyk NTUU “KPI” 1, Filosofiia, psykholohiia, pedahohika, K.: s. 136-138.

10. Seleznova N.P., Seleznov S.V. (2016). Kontent-analiz yakosti ZNO z matematyky. Matematyka v suchasnomu tekhnichnomu universyteti [Content analysis of the quality of external independent evaluation in mathematics. Mathematics in modern technical university]: materialy V Mizhnarodna naukovo-praktychna konferentsiia (Kyiv, 29-30 hrudnia 2016 r.), Kyiv: NTUU “KPI”: s. 248-251.

11. Mazurenko V.P. (2006). Statystyka [Statistics], K.: "Kyivskyi universytet": 315 s. (in Ukrainian)

12. Spearman S. (1904). General intelligence objectwely determined and measured. American Journal of Psychology, 15: p. 201-293.

13. Seleznova N.V., Seleznova N.P., Rudyk T.O. (2012). Zavdannia ta metodychni vkazivky dlia samostiinoi roboty z osnov teorii ymovirnostei [Tasks and guidelines for independent work on the basics of probability theory], Kyiv: $70 \mathrm{~s}$.

14. Sukhodol's'kiy G.V. (2007). Matematika dlya gumanitariev [Mathematics for the humanities], Khar'kov: Gumanitarnyy tsentr: 256 s. (in Russian)

15. Seleznova N.V., Seleznova N.P. (2013). Spetsyfika vykladannia matematychnoi statystyky dlia sotsiolohiv z vykorystanniam suchasnykh kompiuternykh tekhnolohii [Specificity of teaching mathematical statistics for sociologists using modern computer technologies]. Mizhnarodna naukovo-praktychna konferentsiia "Matematyka v suchasnomu tekhnichnomu universyteti”, 19-20 kvitnia Kyiv, K.: NTUU “KPI”: s. 324-327.

16. Alekseev A.N. (1974). Kontent-analiz, ego zadachi, ob"ekty i sredstva [Content analysis, its tasks, objects and means]. Sotsiologiya kul'tury, 1: s. 131-162.

17. Seleznova N.P., Seleznova N.V. (2010). Entropiinyi pidkhid do vyznachennia uzghodzhenosti ekspertnykh otsinok [An entropy approach to determining the coherence of expert assessments]. XIII Mizhnarodna naukova-praktychna konferentsiia imeni akademika M. Kravchuka, 13-15 travnia Kyiv. Materialy konferentsii, 3, K.: s. 104. 